\title{
Potato plant growth and macronutrient uptake as affected by soil tillage and irrigation systems
}

\author{
Julio Cezar Silveira Nunes ${ }^{(1)}$, Paulo Cezar Rezende Fontes ${ }^{(1)}$, Eduardo Fontes Araújo ${ }^{(1)}$ e Carlos Sediyama(1)
}

(1)Universidade Federal de Viçosa, Dep. de Fitotecnia, Av. P.H. Rolfs, CEP 36570-000 Viçosa, MG, Brazil. E-mail: ds06024@correio.ufv.br, pacerefo@ufv.br, efaraujo@ufv.br, csediyama@ufv.br

\begin{abstract}
The objective of this study was to evaluate potato plant growth and macronutrient uptake, as affected by soil tillage methods, in sprinkle and drip irrigated experiments. Eight treatments were set: T1, no tillage, except for furrowing before planting; T2, one subsoiling (SS); T3, twice rotary hoeing (RH); T4, one disc plowing (DP) + twice disc harrow leveling (DL); T5, 1DP + 2DL + 1RH; T6, 1DP + 2DL + 2RH; T7, 1SS + T6; T8, one moldboard plowing (MP) + 2DL. Treatments were arranged in a randomized block design with four replications. In both irrigation systems, plants presented higher emergence velocity index (EVI), when the soil was not tillaged, and the EVI was inversely related to the maximum tuber dry mass production. In both experiments, a functional direct relationship was found between the leaf area index and maximum tuber dry mass yield. The growth of plant organs (tuber, leaf, stem and root) and the macronutrient (N, P, K, Ca and Mg) contents in potato plant responded positively to a deeper soil revolving caused by plowing, especially with moldboard plow.
\end{abstract}

Index terms: Solanum tuberosum, moldboard plow, minimum tillage.

\section{Crescimento da batateira e absorção de macronutrientes influenciados pelos sistemas de preparo de solo e de irrigação}

\begin{abstract}
Resumo - O objetivo deste trabalho foi avaliar o crescimento da batateira e seu acúmulo de macronutrientes, influenciados por métodos de preparo de solo, em experimentos irrigados por aspersão e gotejamento. Em cada experimento, foram estudados oito tratamentos: T1, nenhum preparo do solo, exceto abertura do sulco de plantio; T2, uma subsolagem (SS); T3, duas passadas de enxada rotativa (RH); T4, uma aração com disco (DP) + duas gradagens niveladoras (DL); T5, 1DP + 2DL + 1RH; T6, 1DP + 2DL + 2RH; T7, 1SS + T6; T8, uma aração com aiveca (MP) + 2DL. Os tratamentos foram distribuídos em blocos ao acaso, com quatro repetições. Em ambos os experimentos, nos tratamentos em que o solo não foi arado, as plantas apresentaram alto índice de velocidade de emergência (EVI). A EVI foi inversamente relacionada com a produção de matéria seca de tubérculos. Também, em ambos os experimentos, foi encontrada uma relação funcional direta entre o índice de área foliar e a máxima produção de matéria seca dos tubérculos. O crescimento dos órgãos (tubérculo, folha, caule e raiz) e o conteúdo de macronutrientes $(\mathrm{N}, \mathrm{P}, \mathrm{K}$, Ca e Mg) na planta responderam positivamente à maior profundidade de revolvimento do solo, causada pela aração, especialmente com o arado de aiveca.
\end{abstract}

Termos para indexação: Solanum tuberosum, arado de aiveca, preparo mínimo de solo.

\section{Introduction}

Sequential measurement of dry matter accumulation in both tubers and other plant organs, complemented by leaf area determination, are the essence of growth analysis (Taiz \& Zeiger, 2002). This technique is an integrative, holistic, and explicative approach used to describe and interpret the performance of a given species (Hunt et al., 2002). Plant phenology quantification is an important step in modeling potato plant development, which influence tuber yield (Oliveira, 2000).
The indices determined in the growth analysis indicate the capacity of the plant assimilatory system to synthesize (source) and allocate organic matter into several organs (sink). Such capacity depends on photosynthesis, respiration, and translocation of photoassimilates from the carbon fixation sites to the utilization and storage places, where organ growth and differentiation occur. Thus, growth analysis expresses plant morphophysiological conditions and quantifies the net yield derived from the photosynthetic process, which is influenced by biotic and abiotic factors, as soil preparation methods (Fontes, 2005). 
In Brazil, conventional soil tillage for potato crop normally involves disc plowing, disc leveling and sometimes, rotary hoe at various intensity levels according to soil type (Fontes, 1997). This intensive soil tillage reduces the diameter of the soil aggregates by mechanical effect, produces low quantity of organic residue (Carter \& Sanderson, 2001), and promotes a rapid soil organic matter oxidation and $\mathrm{CO}_{2}$ flow to the atmosphere (Balota et al., 2004).

Recently, changes are occurring regarding environmental care and natural resources conservation. Questions have been made on soil losses due to erosion related to intense soil mobilization. Concern with the excesses verified in soil tillage has led researchers to look for alternative soil tillage systems, such as plowing by zone (Pierce \& Burpee, 1995), reduced plowing (Alva et al., 2002), chisel plow instead of moldboard plow (Carter et al., 1998), and lower number of machinery operations. However, soil tillage must be economically viable, socially accepted, and yield constant results, mainly in relation to disease effects (Sturz et al., 1997).

In this view, no-tillage system, may be a possibility for potato crop. Minimum cultivation and direct planting were developed to save energy, provide soil stability, reduce erosion and make agriculture sustainable. Viability of conventional or reduced tillage for mechanically planted potato has been shown (Ekeberg \& Riley, 1996; Alva et al., 2002; Oliveira, 2003).

The objective of this study was to evaluate the growth and macronutrients accumulation by potato plant, as affected by soil tillage methods in sprinkle and drip irrigated experiments.

\section{Material and Methods}

Two experiments were set up in a Typic Hapludult whose characteristics are in Table 1 . One of the experiments was sprinkler-irrigated and the other, drip-irrigated in adjacent areas of Universidade Federal de Viçosa. The experimental field has a history of conventional tillage (chisel plowing and disking), was previously planted with vegetables, and for the last three years was planted with Stylozobium aterrimum. The area was two times sprayed with glyphosate, at the $75^{\text {th }}$ and $20^{\text {th }}$ days before potato sowing, on May 13, 2003.

In both experiments, eight treatments were evaluated, involving different soil preparation methods, arranged in a randomized block design, with four replications. The useful plot was constituted of four 6-m long rows.The treatments were: $\mathrm{T} 1$, no soil tillage, except for furrowing before planting, also carried out in the other treatments; T2, one subsoiling (SS); T3, twice rotary hoeing (RH); $\mathrm{T} 4$, one disc plowing (DP) + twice disc leveling (DL); T5, 1DP + 2DL + 1RH; T6, 1DP + 2DL + 2RH; T7, 1SS + treatment 6 sequence; T8, one moldboard plowing (MP) +2 DL. Subsoiling was performed at $45 \mathrm{~cm}$ depth, in the places prepared for two central plant rows. All the operations were carried out six days after field irrigation to field capacity and immediately before planting.

After soil tillage and furrowing, 4,000 kg ha-1 of fertilizer $4-14-8,10 \mathrm{~kg} \mathrm{ha}^{-1}$ of borax, $200 \mathrm{~kg} \mathrm{ha}^{-1}$ of magnesium sulphate, and systemic organophosphorated insecticide were applied in the furrows and mixed with the soil. Certified sprouted seed tubers of 'Monalisa' potato were hand-planted in furrows $0.10 \mathrm{~m}$ deep. Seed spacing was $0.31 \mathrm{~m}$ in the row, with rows $0.75 \mathrm{~m}$ apart. The plots consisted of four 6-m long rows. At the $37^{\text {th }}$ day after planting (dap), before the hilling up, sidedress fertilizer application was carried out using $810 \mathrm{~kg} \mathrm{ha}^{-1}$ of ammonium sulphate. During the cycle, fungicides and insecticides were sprayed as necessary.

In the sprinkler-irrigated experiment, the water was applied every seven days. The volume applied was $386 \mathrm{~mm}$ and restored the water evapotranspirated during the period. During the experimental phase, rainfall was not significant.

In the drip-irrigated experiment, a low-pressure drip tube was used with a 0.20 -m emitter spacing and flow rate

Table 1. Some soil physical and chemical properties in 0-20 cm deep, before treatment application.

\begin{tabular}{lcc}
\hline Soil properties & Unit & Average value \\
\hline $\mathrm{pH}($ water suspension 1:2.5) & - & 5.2 \\
$\mathrm{P}($ Mehlich 1) & $\mathrm{mg} \mathrm{dm}^{-3}$ & 165 \\
$\mathrm{~K}($ Mehlich 1) & $\mathrm{mg} \mathrm{dm}^{-3}$ & 313 \\
$\mathrm{Ca}^{2+}\left(\mathrm{KCl} 1 \mathrm{~mol} \mathrm{~L}^{-1}\right)$ & $\mathrm{cmol}_{\mathrm{c}} \mathrm{dm}^{-3}$ & 7.9 \\
$\mathrm{Mg}^{2+}\left(\mathrm{KCl} 1 \mathrm{~mol} \mathrm{~L}^{-1}\right)$ & $\mathrm{cmol}_{\mathrm{c}} \mathrm{dm}^{-3}$ & 1.3 \\
$\mathrm{Al}^{3+}\left(\mathrm{KCl} 1 \mathrm{~mol} \mathrm{~L}^{-1}\right)$ & $\mathrm{cmol}_{\mathrm{c}} \mathrm{dm}^{-3}$ & - \\
Cation exchange capacity & $\mathrm{cmol}_{\mathrm{c} \mathrm{dm}^{-3}}$ & 10.0 \\
Organic matter & $\mathrm{g} \mathrm{kg}^{-1}$ & 26.9 \\
Sand & $\mathrm{g} \mathrm{kg}^{-1}$ & 380 \\
Silt & $\mathrm{g} \mathrm{kg}^{-1}$ & 200 \\
Clay & $\mathrm{g} \mathrm{kg}^{-1}$ & 420 \\
Texture class & - & $\mathrm{Clayey}$ \\
Geometric mean diameter & $\mathrm{mm}^{-3}$ & 1.15 \\
Bulk density & $\mathrm{kg} \mathrm{dm}^{-3}$ & 1.26 \\
Particle density & $\mathrm{kg} \mathrm{dm}^{-3}$ & 2.61 \\
Macroporosity & $\mathrm{m}^{3} \mathrm{~m}^{-3}$ & 0.17 \\
Microporosity & $\mathrm{m}^{3} \mathrm{~m}^{-3}$ & 0.38 \\
Soil humitidy at field capacity & $\mathrm{m}^{3} \mathrm{~m}^{-3}$ & 0.394 \\
Soil humitidy at wilting point & $\mathrm{m}^{3} \mathrm{~m}^{-3}$ & 0.341 \\
Resistance to penetration & $\mathrm{MPa}$ & 1.46 \\
\hline
\end{tabular}


of $4 \mathrm{~L} \mathrm{~h}^{-1} \mathrm{~m}^{-1}$. The tube was placed along each row, following planting. Before the hilling up, the tube was displaced from the original position to avoid being damaged. Over the cycle, $266 \mathrm{~mm}$ of irrigation water were utilized in applications every four days, partly following procedures adopted by Fabeiro et al. (2001).

Up to 25 days after planting, the number of emerged plants was daily quantified. The data obtained were used to calculate the emergence velocity index (EVI), according to Maguire (1962).

In the drip-irrigated experiment, three days after the hilling up, the depth of the soil layer revolved was measured from the hill top. In the minimally cultivated systems, there was no soil layer revolved. In plants collected at 43, 58, 73, 88 and 103 dap, the foliar area and leaf, stem, root and tuber dry weights were determined. The first derivate of the equation adjusted to the dry matter mass of the plant was used to calculate the absolute growth rate of the culture $(G)$.

In the dry matter of the leaf, stem, root, and tubers from treatments T1, T6 and T8 in the sprinkler-irrigated experiment, the nitrogen $(\mathrm{N})$, phosphorous $(\mathrm{P})$, potassium $(\mathrm{K})$, calcium $(\mathrm{Ca})$, and magnesium $(\mathrm{Mg})$ contents were determined; the same procedure was performed in T6 of the drip-irrigated experiment.

In each experiment, the dependent variables were analyzed by variance and regression analyses. In the regression analysis, time (plant age) was considered the independent variable, expressed in days after planting, with the linear, quadratic and cubic effects being tested. The model was selected based on: $F$ test at $5 \%$ probability, biological significance, and the highest $\mathrm{R}^{2}$ value.

\section{Results and Discussion}

In the drip-irrigated experiment, plant emergence started at 10 dap and completed at 17 dap. In the sprinkle-irrigated experiment these values were 12 and 23 dap, half the time observed by Fabeiro et al. (2001), under other experimental conditions. In both experiments, there was effect of treatments on EVI, which was higher in T1 (Table 2). This indicates that the most rapid emergence occurred in the treatments with no soil plowing. Before emerging, the potato plant emits a profuse root system, which has its growth limited in compacted soil (Lesczynski \& Tanner, 1976). In the treatments, where the soil was not plowed, the mother-tuber might have directed its reserves to a more rapid stem emission, due to the greater resistance to root growth.

EVI was lower in the sprinkle-irrigated experiment than in the drip-irrigated one, probably due to the formation of a superficial soil layer compacted by the impact of water drops applied. Lower EVI was verified in sprinkle-irrigated soybean plants than in drip-irrigated ones (Wang et al., 2000), due to the higher temperature of the drip-irrigated soil, as well as due to the maintenance of the soil surface physical structure, which did not favor the formation of a compacted layer.

EVI (plant per day) presented inverse functional relationship with the maximum tuber dry weight (g per plant) in both experiments: drip-irrigated ( $\mathrm{Y}=156.81$ - 13.67X, $r=0.79 *)$; and for sprinkler-irrigated experiment $(\mathrm{Y}=126.60$ - 9.78X, $\mathrm{r}=0.83 *$ ).

In both experiments, the treatments did not influence the dry matter partition in the plant, with $68 \%$ of the maximum dry matter produced by the plant being allocated in the tubers, $22 \%$ in the leaves, $7 \%$ in the stems and 3\% in the roots. Dry matter partitioning pattern in potato plant is greatly influenced by the presence of the tubers, which are very strong sinks for assimilates. Any factor influencing the partitioning pattern of tubers would be of considerable significance for yield formation (Jenkins \& Mahmood, 2003).

The treatments resulted in similar forms of mathematical equations representatives of plant organ growth in function of time, but with different maximum values (Table 3). The values were higher in T8, where the soil was moldboard plowed, lower in T1 where minimal cultivation was performed without soil revolving, and intermediary in treatments T2 through T7. The soil

Table 2. Maximum potato leaf area index (LAI) and plant emergence velocity index (EVI) in the treatments, in drip and sprinkler-irrigated experiments ${ }^{(1)}$.

\begin{tabular}{|c|c|c|c|c|}
\hline \multirow[t]{2}{*}{ Treatment } & \multicolumn{2}{|c|}{ Drip } & \multicolumn{2}{|c|}{ Sprinkler } \\
\hline & $\begin{array}{c}\text { LAI } \\
\left(\mathrm{cm}^{2} \mathrm{~cm}^{-2}\right)\end{array}$ & $\begin{array}{l}\text { EVI } \\
\text { (plants } \\
\text { per day) }\end{array}$ & $\begin{array}{c}\text { LAI } \\
\left(\mathrm{cm}^{2} \mathrm{~cm}^{-2}\right)\end{array}$ & $\begin{array}{c}\text { EVI } \\
\text { (plants } \\
\text { per day) }\end{array}$ \\
\hline T1. No-tillage & $1.83 \mathrm{C}$ & $7.0 \mathrm{~A}$ & $1.75 \mathrm{D}$ & $5.5 \mathrm{~A}$ \\
\hline T2. 1SS & $1.68 \mathrm{C}$ & $6.3 \mathrm{AB}$ & $1.78 \mathrm{D}$ & $5.0 \mathrm{~A}$ \\
\hline T3. $2 \mathrm{RH}$ & $2.45 \mathrm{AB}$ & $6.5 \mathrm{AB}$ & $2.23 \mathrm{C}$ & $4.8 \mathrm{~A}$ \\
\hline $\mathrm{T} 4.1 \mathrm{DP}+2 \mathrm{DL}$ & $1.98 \mathrm{C}$ & $6.5 \mathrm{AB}$ & $2.50 \mathrm{BC}$ & $3.4 \mathrm{~B}$ \\
\hline $\mathrm{T} 5.1 \mathrm{DP}+2 \mathrm{DL}+1 \mathrm{RH}$ & $2.43 \mathrm{AB}$ & $6.0 \mathrm{AB}$ & $2.39 \mathrm{C}$ & $4.0 \mathrm{AB}$ \\
\hline T6. $1 \mathrm{DP}+2 \mathrm{DL}+2 \mathrm{RH}$ & $2.08 \mathrm{~B}$ & $5.8 \mathrm{~B}$ & $2.46 \mathrm{BC}$ & $5.2 \mathrm{~A}$ \\
\hline $\mathrm{T} 7 \cdot 1 \mathrm{SS}+1 \mathrm{DP}+2 \mathrm{DL}+2 \mathrm{RH}$ & $2.52 \mathrm{~A}$ & $5.6 \mathrm{~B}$ & $2.78 \mathrm{AB}$ & $3.8 \mathrm{AB}$ \\
\hline $\mathrm{T} 8.1 \mathrm{MP}+2 \mathrm{DL}$ & $2.81 \mathrm{~A}$ & $5.5 \mathrm{~B}$ & $3.06 \mathrm{~A}$ & $3.8 \mathrm{AB}$ \\
\hline
\end{tabular}

(1)Within columns, means followed by equal letters are not significantly different at $\mathrm{p}<0.05$ (Newman-Keuls test). 
tillage and management systems interfered directly in plant development and productivity due to effects on density, porosity and water storage in the soil profile, according to Pereira et al. (2004).

The lowest root dry weight was verified in T1, no-tillaged soil (Table 3). Root, shoot and tuber had difficulty in developing in no revolved soil, under the minimum tillage (T1 and T2), and grew less than under the systems where the soil was revolved. For a wide range of soil type, lower growth occurred, when plants were cultivated in direct planting compared to planting in prepared soil (Schmidt \& Belford, 1994). Poor wheat root growth found in direct-drilled soils, which was significantly related to poor shoot growth, was not caused by soil higher bulk density, but by biological factors involved, as soil fumigation completely eliminated poor shoot growth (Chan \& Mead, 1992). Also, in no-tillaged soils, an inhibitory root signal may occur, which has been shown under controlled conditions, to reduce shoot growth in hard soil, even when leaves are well supplied with water and nutrients (Stirzaker et al., 1993).

The depth of soil plow layer in T1, T6 and T8 was 0 , 24 and $30 \mathrm{~cm}$, respectively (Table 4), and tends to follow the order: disc harrow plow + moldboard plow $>$ moldboard plow $>$ disc harrow leveling + disc plow $>$ disc plow $>$ disk harrow plow (Radosevich et al., 1996). No-tillage reduces soil mechanic revolving and preserves the cultural residues on the soil surface. A beneficial effect of deep preparation on the potato roots and tubers development is reported (Bishop \& Grimes, 1978), although deep preparation may not always be advantageous (Pierce \& Burpee, 1995).

In both experiments, the effects of the treatments on the leaf area index (LAI) were similar to those verified on the plant dry weight, being LAI higher in T8 (Table 2). Young et al. (1993) found the highest LAI, and stem, stolon and potato tuber dry weight, in soil where resistance to penetration was lower, due to lower machinery traffic in the area. Maximum LAI was obtained at 61 dap, on treatment average, similarly to the findings of Melo et al. (2003) for an early-maturing potato variety. In early-maturing potato cultivars, new leaf production ceases at a relatively early stage, and dry matter partition for the tubers occurs at a relatively low total plant dry weight (Jenkins \& Mahmood, 2003). Higher LAI value indicates higher foliar area for the solar radiation interception and, within determined limits, also indicates greater potato tuber growth and production (Midmore, 1988). LAI $\left(\mathrm{cm}^{2} \mathrm{~cm}^{-2}\right)$ presented a direct and positive functional relationship with maximum tuber dry weight ( $\mathrm{g}$ per plant) in both experiments: drip-irrigated $\left(\mathrm{Y}=28.48+19.90 \mathrm{X}, \mathrm{r}=0.86^{*}\right)$; and sprinkler-irrigated $\left(\mathrm{Y}=35.22+20.26 \mathrm{X}, \mathrm{r}=0.98^{* *}\right)$.

The highest and the lowest nutrient uptake were verified in $\mathrm{T} 8$ and $\mathrm{T} 1$, respectively (Table 4). Under no-tillage, the soil tends to accumulate lower moisture and presents greater soil strength than soil in a conventional tillage system (Cannell, 1985). High density reduces the soil capacity for retaining water, restricting nutrient absorption by the root (Carter et al., 1998). Soil conditions may alter root growth and affect shoot growth and nutrient uptake indirectly (Qin et al., 2005). In maize and sorghum cultures, Canalli \& Roloff (1997) observed a greater exploration of the soil by the roots, when the soil was revolved with moldboard plow, compared with disc plow and rotary hoe. Under no-tillage system, soil solution $\mathrm{pH}$ was lower than under conventional tillage, and was inversely related to total organic carbon concentration in soil solution and precipitation (Lilienfein et al., 2000). Such conditions may alter nutrient availability in the soil. Ekeberg \& Riley (1996) found no significant difference in $\mathrm{N}$ uptake by potato tuber between no-tillage and conventional tillage systems.

In the sprinkler-irrigated experiment, the maximum nutrient uptake in plants in T6, expressed in $\mathrm{kg} \mathrm{ha}^{-1}$, were: N, 109; P, 14; K, 195; Ca, 30; and Mg, 19 (Table 4).

Table 3. Maximum estimated values of leaf, stem, root, and potato tuber dry weight (DW), plant growth rate (G) and tuber growth rate $\left(\mathrm{G}_{\mathrm{T}}\right)$ in T1, T6, and T8 treatments, in drip and sprinkler irrigated experiments ${ }^{(1)}$.

\begin{tabular}{|c|c|c|c|c|c|c|}
\hline \multirow[t]{2}{*}{ Characteristic } & \multicolumn{3}{|c|}{ Drip } & \multicolumn{3}{|c|}{ Sprinkler } \\
\hline & T1 & T6 & T8 & $\mathrm{T} 1$ & $\mathrm{~T} 6$ & T8 \\
\hline Leaf DW (g per plant) & $20.9 \mathrm{~B}$ & $23.7 \mathrm{AB}$ & $28.3 \mathrm{~A}$ & $22.6 \mathrm{~B}$ & $28.8 \mathrm{AB}$ & $31.4 \mathrm{~A}$ \\
\hline Stem DW & $6.9 \mathrm{~B}$ & $6.5 \mathrm{~B}$ & $9.2 \mathrm{~A}$ & $7.3 \mathrm{~B}$ & 8.6AB & $10.1 \mathrm{~A}$ \\
\hline Root DW & $1.80 \mathrm{~B}$ & $2.41 \mathrm{~A}$ & $3.00 \mathrm{~A}$ & $2.40 \mathrm{~B}$ & $3.31 \mathrm{~A}$ & $3.80 \mathrm{~A}$ \\
\hline Tuber DW & $61.5 \mathrm{~B}$ & $72.2 \mathrm{AB}$ & 86.9A & $70.6 \mathrm{~B}$ & 84.1AB & $96.6 \mathrm{~A}$ \\
\hline Plant DW & $91.1 \mathrm{~B}$ & $104.8 \mathrm{AB}$ & $127.4 \mathrm{~A}$ & $102.9 \mathrm{~B}$ & $124.8 \mathrm{AB}$ & $141.9 \mathrm{~A}$ \\
\hline G (g per plant per day) & $1.10 \mathrm{~B}$ & $2.50 \mathrm{~A}$ & $2.85 \mathrm{~A}$ & $1.90 \mathrm{C}$ & $2.97 \mathrm{~B}$ & $4.08 \mathrm{~A}$ \\
\hline $\mathrm{G}_{\mathrm{T}}$ (g per plant per day) & $0.79 \mathrm{~B}$ & $1.68 \mathrm{~A}$ & $1.90 \mathrm{~A}$ & $0.99 \mathrm{~B}$ & $2.01 \mathrm{~A}$ & $2.74 \mathrm{~A}$ \\
\hline
\end{tabular}

${ }^{(1)}$ Within rows, in each experiment, means followed by equal letters are not significantly different at $\mathrm{p}<0.05$ (Newman-Keuls test). 
In the drip-irrigated experiment $\mathrm{T} 6$, the corresponding values ( $\mathrm{kg} \mathrm{ha}^{-1}$ ) were: $\mathrm{N}, 77$; P, 10; K, 106; Ca, 24; and $\mathrm{Mg}, 13$. These values are within the range cited as normal (Perrenoud, 1993). Plant nutrient uptake is the result of three processes, namely, absorption, translocation, and incorporation, and correlates well with plant growth and dry matter production (Fontes, 2001). Nitrogen and potassium accumulation curves along the plant cycle in T6 presented higher values in the sprinkler-irrigated experiment (Figure 1). The same occurred for calcium, phosphorus and magnesium (Figure 2). For all nutrients, the uptake efficiency, considered as plant maximum estimated dry weight, divided by the maximum nutrient uptake, was higher in the drip-irrigated experiment (Table 5).

Table 4. Soil plow layer depth (SPD) and maximum nutrient uptake ( $\left.\mathrm{kg} \mathrm{ha}^{-1}\right)$ by potato plant in T1, T6, and T8 treatments, in sprinkler-irrigated experiment ${ }^{(1)}$.

\begin{tabular}{lccc}
\hline Characteristic & \multicolumn{3}{c}{ Treatments } \\
\cline { 2 - 4 } & $\mathrm{T} 1$ & $\mathrm{~T} 6$ & $\mathrm{~T} 8$ \\
\hline SPD $(\mathrm{cm})$ & 0 & $23.9 \mathrm{~B}$ & $29.6 \mathrm{~A}$ \\
Nitrogen & $85 \mathrm{~B}$ & $109 \mathrm{~A}$ & $110 \mathrm{~A}$ \\
Phosphorus & $18 \mathrm{~A}$ & $14 \mathrm{~B}$ & $19 \mathrm{~A}$ \\
Potassium & $170 \mathrm{~B}$ & $195 \mathrm{~A}$ & $194 \mathrm{~A}$ \\
Calcium & $25 \mathrm{C}$ & $30 \mathrm{~B}$ & $34 \mathrm{~A}$ \\
Magnesium & $14 \mathrm{~B}$ & $19 \mathrm{~A}$ & $15 \mathrm{AB}$ \\
\hline
\end{tabular}

(1)Within rows, means followed by equal letters are not significantly different at $\mathrm{p}<0.05$ (Newman-Keuls test).

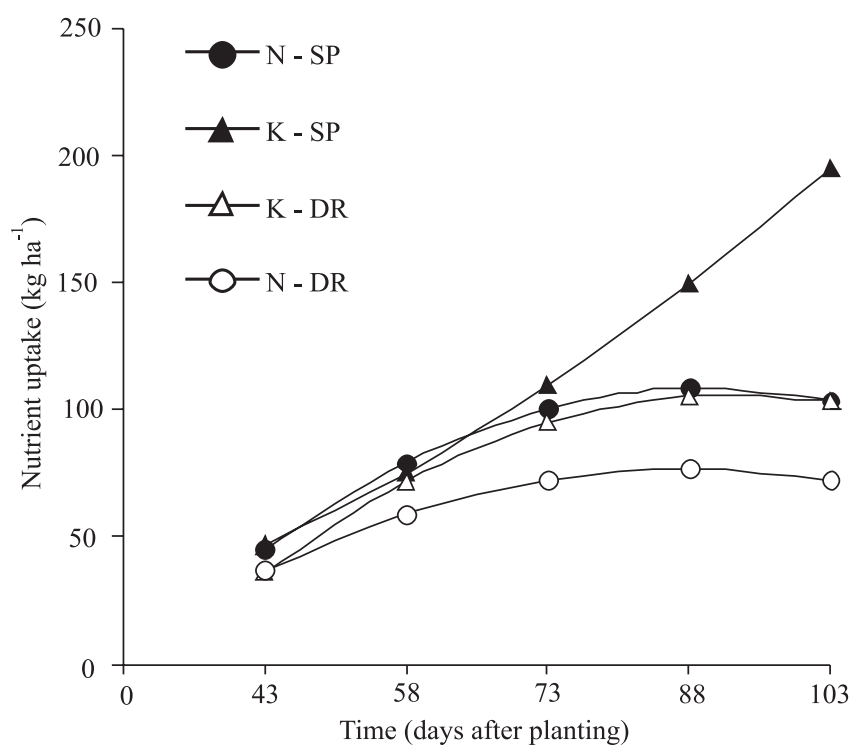

Figure 1. Relationships between harvest time and nitrogen (N) and potassium (K) uptake by potato plant in T6, in sprinkler (SP) and drip-irrigated (DR) experiments.

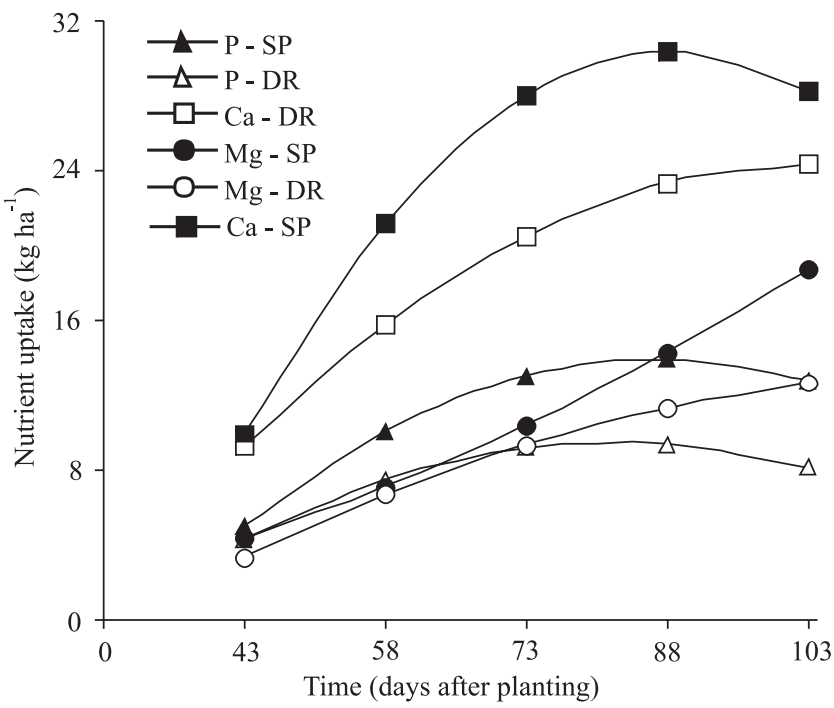

Figure 2. Relationship between harvest time and calcium (Ca), phosphorus (P), and magnesium (Mg) uptake by potato plant in T6, in sprinkler (SP) and drip-irrigated (DR) experiments.

Table 5. Nutrient uptake efficiency ${ }^{(1)}$ in potato plant in T6, in drip and sprinkler-irrigated experiments ${ }^{(2)}$.

\begin{tabular}{lrc}
\hline Nutrient & Drip & Sprinkler \\
\hline Nitrogen & $59 \mathrm{~A}$ & $49 \mathrm{~B}$ \\
Phosphorus & $479 \mathrm{~A}$ & $386 \mathrm{~B}$ \\
Potassium & $42 \mathrm{~A}$ & $28 \mathrm{~B}$ \\
Calcium & $189 \mathrm{~A}$ & $175 \mathrm{~A}$ \\
Magnesium & $366 \mathrm{~A}$ & $289 \mathrm{~B}$ \\
\hline
\end{tabular}

(1)Maximum plant dry weight $\left(\mathrm{kg} \mathrm{ha}^{-1}\right) /$ maximum nutrient uptake $\left(\mathrm{kg} \mathrm{ha}^{-1}\right){ }^{(2)}$ Within rows, means followed by equal letters are not significantly different at $\mathrm{p}<0.05$ (Newman-Keuls test).

\section{Conclusion}

The growth of plant organs and the macronutrient uptake in potato plant respond positively to a deeper soil revolving caused by plowing, especially with moldboard plow, for both sprinkler and drip-irrigated experiments.

\section{Acknowledgements}

To Fapemig and to CNPq, for scholarships granted.

\section{References}

ALVA, A.K.; HODGES, T.; BOYDSTON, R.A.; COLLINS, H.P. Effects of irrigation and tillage practices on yield of potato under high production conditions in the Pacific Northwest. Communications in Soil Science and Plant Analysis, v.33, p.1451-1460, 2002. 
BALOTA, E.L.; COLOZZI FILHO, A.; ANDRADE, D.S.; DICK, R.P. Long-term tillage and crop rotation effects on microbial biomass and $\mathrm{C}$ and $\mathrm{N}$ mineralization in a Brazilian Oxisol. Soil and Tillage Research, v.77, p.137-145, 2004.

BISHOP, J.C.; GRIMES, D.W. Precision tillage effects on potato root and tuber production. American Potato Journal, v.55, p.6571, 1978.

CANALLI, L.B.; ROLOFF, G. Influência do preparo e da correção do solo na condição hídrica de um LVE sob plantio direto. Revista Brasileira de Ciência do Solo, v.21, p.99-104, 1997.

CANNELL, R.Q. Reduced tillage in Northwest Europe - a review. Soil and Tillage Research, v.5, p.129-177, 1985.

CARTER, M.R.; SANDERSON, J.B. Influence of conservation tillage and rotation length on potato productivity, tuber disease and soil quality parameters on a fine sandy loam in Eastern Canada. Soil and Tillage Research, v.63, p.1-13, 2001.

CARTER, M.R.; SANDERSON, J.B.; MacLEOD, J.A. Influence of time of tillage on soil physical attributes in potato rotations in Prince Edward Island. Soil and Tillage Research, v.49, p.127137, 1998.

CHAN, K.Y.; MEAD, J.A. Tillage-induced differences in the growth and distribution of wheat-roots. Australian Journal of Agricultural Research, v.43, p.19-28, 1992.

EKEBERG, E.; RILEY, H.C.F. Effects of mouldboard ploughing and direct planting on yield and nutrient uptake of potatoes in Norway. Soil and Tillage Research, v.39, p.131-142, 1996.

FABEIRO, C.; SANTA OLALLA, F.M. de; JUAN, J.A. de. Yield and size of deficit irrigated potatoes. Agricultural Water Management, v.48, p.255-266, 2001.

FONTES, P.C.R. Cultura da batata. In: FONTES, P.C.R. (Ed.). Olericultura: teoria e prática. Viçosa: DFT/UFV, 2005. p.323-343. FONTES, P.C.R. Diagnóstico do estado nutricional das plantas. Viçosa: UFV, 2001. 122p.

FONTES, P.C.R. Preparo do solo, nutrição mineral e adubação da batateira. Viçosa: UFV, 1997. 42p.

HUNT, R.; CAUSTON, D.R.; SHIPLEY, B.; ASKEW, P. A modern tool for classical plant growth analysis. Annals of Botany, v.90, p.485-488, 2002.

JENKINS, P.D.; MAHMOOD, S. Dry matter production and partitioning in potato plants subjected to combined deficiencies of nitrogen, phosphorus and potassium. Annals of Applied Biology, v.143, p.215-229, 2003.

LESCZYNSKI, D.B.; TANNER, C.B. Seasonal variation of root distribution of irrigated field-grown Russet Burbank potato. American Potato Journal, v.53, p.69-78, 1976.

LILIENFEIN, J.; WILCKE, W.; LIMA, S.C.; THOMAS, R.; ZECH, W. Nutrient concentrations in soil solution of some Brazilian Oxisols under conventional and no-tillage systems in the early part of the rainy season. Australian Journal of Soil Research, v.38, p.851866, 2000.

MAGUIRE, J.D. Speeds of germination-aid selection and evaluation for seedling emergence and vigor. Crop Science, v.2, p.176-177, 1962.
MELO, P.C.T. de; GRANJA, N. do P.; MIRANDA FILHO, H. da S.; SUGAWARA, A.C.; OLIVEIRA, R.F. de. Análise do crescimento da cultivar de batata Ágata. Batata Show, v.3, p.16-17, 2003.

MIDMORE, D.J. Potato (Solanum spp.) in the hot tropics. VI. Plant population effects on soil temperature, plant development and tuber yield. Field Crops Research, v.19, p.183-200, 1988.

OLIVEIRA, A.D. Desenvolvimento e avaliação operacional do protótipo UFV-ENG para o plantio direto de batata. 2003. 129p. Tese (Doutorado) - Universidade Federal de Viçosa, Viçosa.

OLIVEIRA, C.A.S. Potato growth as affected by nitrogen and plant density. Pesquisa Agropecuária Brasileira, v.35, p.935-950, 2000.

PEREIRA, J.C.R.; RODRIGUES, R.A.F.; ARF, O.; ALVAREZ, A.C.C. Influência do manejo do solo, lâminas de água e doses de nitrogênio na produtividade do feijoeiro. Acta Scientiarum: Agronomy, v.26, p.13-19, 2004.

PERRENOUD, S. Potato fertilizer for yield and quality. $2^{\text {nd }}$ ed. Basel: International Potash Institute, 1993. 94p. (Bulletin, 8).

PIERCE, F.J.; BURPEE, C.G. Zone tillage effects on soil properties and yield and quality of potatoes (Solanum tuberosum L.). Soil and Tillage Research, v.35, p.135-146, 1995.

QIN, R.J.; STAMP, P.; RICHNER, W. Impact of tillage and banded starter fertilizer on maize root in the top 25 centimeters of the soil. Agronomy Journal, v.97, p.674-683, 2005.

RADOSEVICH, S.; HOLT, J.; GHERSA, C. Weed ecology: implication for management. $2^{\text {nd }}$ ed. New York: Wiley, 1996. 573p.

SCHMIDT, C.P.; BELFORD, R.K. Increasing the depth of soil disturbance increases yield of direct drilled wheat on the sandplain soil of Western Australia. Australian Journal of Experimental Agriculture, v.34, p.777-781, 1994.

STIRZAKER, R.J.; PASSIOURA, J.B.; SUTTON, B.G.; GEORGE, N.C. Soil management for irrigated vegetable production. II. Possible causes for slow vegetative growth of lettuce associated with zero tillage. Australian Journal of Agricultural Research, v.44, p.831844, 1993.

STURZ, A.V.; CARTER, M.R.; JOHNSTON, H.W. A review of plant disease, pathogen interactions and microbial antagonism under conservation tillage in temperate humid agriculture. Soil and Tillage Research, v.41, p.169-189, 1997.

TAIZ, L.; ZEIGER, E.E. Plant physiology. $3^{\text {rd }}$ ed. Sunderland: Sinauer Associates, 2002. 690p.

WANG, D.; SHANNON, M.C.; GRIEVE, C.M.; YATES, S.R. Soil water and temperature regimes in drip and sprinkler irrigation, and implications to soybean emergence. Agricultural Water Management, v.43, p.15-28, 2000.

YOUNG, I.M.; BENGOUGH, A.G.; MACKENZIE, C.J.; DICKSON, J.W. Differences in potato development (Solanum tuberosum cv. Maris Piper) in zero and conventional traffic treatments are related to soil physical conditions and radiation interception. Soil and Tillage Research, v.26, p.341-359, 1993. 